\section{Composition data of a large collection of black-appearing Roman glass}

\author{
Simone Cagno, ${ }^{1}$ Peter Cosyns, ${ }^{2}$ \\ Veerle Van der Linden, ${ }^{1}$ Olivier Schalm, ${ }^{3}$ \\ Andrei Izmer, ${ }^{4}$ Isolde Deconinck, ${ }^{4}$ \\ Frank Vanhaecke, ${ }^{4}$ Anna Nowak, ${ }^{5}$ \\ Barbara Wagner, ${ }^{5}$ Ewa Bulska, ${ }^{5}$ \\ Karin Nys, ${ }^{2}$ Koen Janssens ${ }^{1}$ \\ 1 Department of Chemistry, University \\ of Antwerp, Antwerp; ${ }^{2}$ Mediterranean \\ Archaeological Research Institute, Vrije \\ Universiteit Brussel, Brussels; \\ ${ }^{3}$ Faculty of Design Sciences, University \\ of Antwerp, Antwerp; ${ }^{4}$ Department of \\ Analytical Chemistry, University of \\ Ghent, Ghent, Belgium; ${ }^{5}$ Faculty of \\ Chemistry, University of Warsaw, \\ Warsaw, Poland
}

\section{Abstract}

Jewels and tableware made of black-appearing glass were popular in the Roman Empire. Compositional changes (due to modifications in glassmaking technology and use of raw materials) over the period considered $\left(1^{\text {st }}-5^{\text {th }}\right.$ century AD) have been investigated on a large number of samples originating from various archaeological excavations in Europe, Northern Africa and the Near East. In the course of this work, over 400 samples of Roman glass, the greatest part of them deeply coloured glass fragments, were embedded into acrylic resin and mechanically ground and polished in order to obtain flat surfaces of unaltered glass. The samples were analysed with scanning electron microscopy/energy dispersive X-ray spectroscopy and the quantification was performed by using a standard-less ZAF software. The trace elements contained in a selection of glass samples were determined via laser ablation-inductively coupled plasmamass spectrometry. The data collected in this study show that from about $150 \mathrm{AD}$ a change in the black glass production process occurred, involving coloration of raw glass made with iron in the secondary workshops. Furthermore, from the $4^{\text {th }}$ century $\mathrm{AD}$ on we can observe a change in the type of raw glass used, while the colouring process was maintained. The main aim of this paper is to provide glass scholars with the analysis results, as reference and comparison for further studies.

\section{Introduction}

The introduction of glassblowing halfway through the $1^{\text {st }}$ century $\mathrm{BC}$ turned glass from an expensive luxury material into an affordable commodity: the glass market expanded and large amounts of glass were produced in order to satisfy the needs of the consumers in Rome and its provinces. In this context it is interesting to explore the dynamics and locations of glassmaking and glassworking.

Between the Hellenistic and the Byzantine period the technological level and conditions required to control glassmaking were significantly more elevated than those needed for glassworking (Stern and Schlick-Nolte, 1994; Stern, 1999). In order to manufacture glass objects, glassworkers in secondary glass workshops melted and shaped raw glass obtained from primary workshops. It is generally accepted that during the Roman imperial period glass objects were manufactured in secondary glass workshops all over the Empire by re-melting and shaping raw glass imported from primary workshops which are located in the south-eastern Mediterranean with the Egyptian and the Syro-Palestinian coast as key areas (Foy, 2000; Nenna, 2008; Jackson et al., 2009). These primary workshops were located close to the raw material supplies, using lime-rich coastal sand and natron to produce large slabs of glass. From the primary centers the raw glass was then shipped (in large chunks) along the trade routes to the secondary workshops throughout the Roman Empire (Nenna, 2008; Henderson, 1985; Velde, 1990; Freestone et al., 2000; Freestone, 2006; Picon and Vichy, 2003; Fontaine and Foy, 2007). However, it has also been suggested that in the Roman period primary glassmaking might have occurred in the Italian peninsula as well as in Spain and Gaul likewise Pliny the Elder's statement in his Naturalis Historia (Silvestri et al., 2006; Degryse and Schneider, 2008; Foster and Jackson, 2009).

Previously we proposed that, in a first phase, the craftsmen's knowledge in the western provinces was limited to the production of objects by re-melting imported naturally colored, deeply colored and decolorised raw glass and cullet. In a later phase at about the mid $2^{\text {nd }}$ century $\mathrm{AD}$ the expertise got enriched with the acquaintance in how to obtain independently the color of the (remelted) glass batch (Van der Linden et al., 2009). A logical deduction is that a final stage in the accumulation of glass craftsmen's knowledge in the western part of the Roman Empire comprises the know-how to produce raw glass locally by means of imported natron may have been reached in some regions during the late Roman period. This evolution in knowledge in glass production technology is one of two possible models for
Correspondence: Simone Cagno, Department of Chemistry, University of Antwerp, Groenenborgerlaan 171, 2020 Antwerp, Belgium. Tel. +32.32652363 - Fax: +32.32652376.

E-mail: simone.cagno@ua.ac.be

Key words: historical black glass, Roman Empire, composition, SEM-EDX, LA-ICP-MS.

Citation: Cagno S, Cosyns P, Van der Linden V, Schalm 0, Izmer A, Deconinck I, Vanhaecke F, Nowak A, Wagner B, Bulska E, Nys K, Janssens K, 2013. Composition data of a large collection of black-appearing Roman glass. In: RH Tykot (ed.) Proceedings of the $38^{\text {th }}$ International Symposium on Archeometry - May $10^{\text {th }}-14^{\text {th }} 2010$, Tampa, Florida. Open Journal of Archaeometry 1:e22.

Acknowledgements: this research was supported by the Interuniversity Attraction Poles Programme - Belgian Science Policy (IUAP VI/16). The text also presents results of GOA XANES meets ELNES (Research Fund University of Antwerp, Belgium) and from FWO (Brussels, Belgium) projects no. G.0704.08 and G.01769.09. The Authors EB and BW acknowledge financial support from the Ministry of Science and High Education of Poland, research project N N204 241734.

Presented at the $38^{\text {th }}$ International Symposium on Archaeometry - May $10^{\text {th }}-14^{\text {th }} 2010$, Tampa, Florida.

This work is licensed under a Creative Commons Attribution 3.0 License (by-nc 3.0).

(C) Copyright S. Cagno et al., 2013

Licensee PAGEPress, Italy

Open Journal of Archaeometry 2013; 1:e22

doi:10.4081/arc.2013.e22

glass production in the late Roman period (Shortland et al., 2006; Wedepohl and Baumann, 2000). A second model suggests the continuation of large primary glass centers in the eastern Mediterranean (Foy et al., 2000; Freestone et al., 2005).

In a first period, from Tiberian to Flavian times, so-called black glass was one of the hues used to produce the fashionable deeply colored monochrome glass vessels which received an empire wide distribution (Cosyns and Fontaine, 2006). The subsequent production period of black appearing glass vessels lasted from the mid $2^{\text {nd }}$ to the mid $3^{\text {rd }}$ century $\mathrm{AD}$ and had only a regional impact on the consumption as it was limited to the north-western provinces Gallia Belgica, Germania inferior and Germania superior (Cosyns and Hanut, 2005; Cosyns et al., 2006). Influenced by the success of black appearing jewelry in jet and other materials there is a huge increase from the $3^{\text {rd }}$ century $\mathrm{AD}$ onwards in using black glass to produce jewelry - bangles, finger-rings, beads, pendants, hairpins, and gems. Affected 
by the invasions of the Migration People this production gradually disappeared during the $5^{\text {th }}$ century $\mathrm{AD}$ in the western part with solely black glass beads in combination with trailed decoration in vivid colored opaque glass remaining in use up to the mid $6^{\text {th }}$ century AD. Conversely, a continuity of a wide range of jewelry production in black glass can be observed within the Byzantine Empire (Cosyns, 2011).

Because of its unusual time- and locationspecific distribution, black glass is a useful type of archaeological find to be studied in order to explore in a more detailed way the relation between primary and secondary glass workshops and the trade among them.

The aim of this paper is to provide scholars with a substantial number of analysis results of Roman black glass fragments, as a reference and comparison for further studies. Data relative to the over 400 analysed samples are presented here. A basic interpretation of the data is provided in the present paper, whereas the statistical reduction of the data and a wide descriptive interpretation is provided elsewhere (Van der Linden et al., 2009). Not many analyses of black glass have been published up to now. The earliest analytical results of European black glass are those of a set of European glass beads originating from France and Switzerland (Gratuze, 2009; Cagno et al. 2014). The Bronze Age samples in this series are ash-fluxed, while the Iron Age ones are natron-fluxed, (low levels of $\mathrm{MgO}$ and $\mathrm{K}_{2} \mathrm{O}$ ) and containing low amounts of $\mathrm{CaO}$. In both cases, the black color is obtained by a notably high amount of $\mathrm{Fe}_{2} \mathrm{O}_{3}$, comprised between 10 and $25 \%$.

Among the published analytical results of Bronze and Iron Age glass material from Pella, Jordan (Reade et al., 2009), the black glass, natron fluxed, is rather different from the glass produced in that same period. The composition is similar to the aforementioned Iron Age glass and the color of the glass is determined by the high percentage of iron present.

Besides that, Pre-Roman dark glass beads from Belgium, dated to the $2^{\text {nd }}$ quarter of the $3^{\text {rd }}$ century BC (Cosyns and Hurt, 2007), analysed via laser ablation-inductively coupled plasmamass spectrometry (LA-ICP-MS) show two different compositions. The first one (black/green glass) can be confidently attributed to the Syro-Levantine glass type, with a significant voluntary addition of iron in order to render the glass black, while the second (brown glass) has a more difficult interpretation. Compositions of more samples of dark glass from the Iron Age to the late antiquity are also reported; these are all of the SyroLevantine high-iron type (Cosyns and Gratuze, 2007).

In the Low Countries, a precursor of the black-appearing Roman glass is the La Tène dark purple glass. Large quantities of purple glass jewelry dated to the late La Tène period ( $2^{\text {nd }} 1^{\text {st }}$ century $\left.B C\right)$ have been found in the central area of the Netherlands. The composition of only a few fragments of such glass is published (together with others results) by Van der Linden et al. (2009). This glass has a composition similar to naturally-colored natron-based glass, but with a high content of manganese. Presumably a significant amount of a Mn mineral was used in order to obtain the desired dark purple/black hue. For what concerns black-appearing Roman glass, a first compilation of data is presented in Van der Linden et al. (2009). The most abundant and widespread type of coloration is the black/green one. Two different compositions could be distinguished among the black/green sample set: a low iron group (1-2\% $\left.\mathrm{Fe}_{2} \mathrm{O}_{3}\right)$, associated with the Early Roman imperial period up to about $150 \mathrm{AD}$, and a high iron one, containing $4-10 \% \mathrm{Fe}_{2} \mathrm{O}_{3}$, typical of the period after $150 \mathrm{AD}$. Those data are also implemented in this paper, for comparison purposes.

\section{Materials and Methods}

Over 400 archaeological samples have been selected for analysis including black-appearing glass, deeply colored glass and colorless glass. The two latter color groups only represent a minor set of samples which have been chosen for comparison. The samples cover the whole area of the Roman Empire and the period $1^{\text {st }}-5^{\text {th }}$ century AD.

Small glass fragments were removed from the archaeological finds and embedded into acrylic resin. The resin blocks were mechanically ground with silicon carbide paper and polished with diamond paste up to $0.25 \mu \mathrm{m}$ in order to obtain a smooth surface of unaltered glass. Finally the resin blocks were coated with a thin carbon layer and scanning electron microscope-energy-dispersive X-ray spectroscopy (SEM-EDX) measurements were performed. After the removal of the carbon layer, the same sets of resin blocks were used for LAICP-MS analyses.

SEM-EDX measurements were performed in Antwerp, Belgium, with a JEOL 6300 SEM equipped with an energy-dispersive X-ray detector. The spectra were collected for 100 seconds by using a 2 nA electron beam current, an accelerating voltage of $20 \mathrm{kV}$ and a microscope magnification of 500 . The net intensities were calculated with the program AXIL and quantified by means of a standardless ZAF programme (Schalm and Janssens, 2003).

The LA-ICP-MS measurements were performed on selected samples in two laboratories in Warsaw, Poland, and Ghent, Belgium.

In Warsaw an ELAN 9000 ICP-MS equipped with the LA system LSX-200+ was used. The
LSX-200+ contains a stable, environmentally sealed $266 \mathrm{~nm}$ UV Nd:YAG laser with a high sampling efficiency, variable pulse repetition rate and maximum energy up to $6 \mathrm{~mJ}$ per pulse. More details on the instrumental conditions can be found in literature (Van der Linden et al., 2009). Line-scan measurements were performed on each sample: a measurement cycle consisted of pre-cleaning the sample surface with a laser beam (no signal was registered during this step) followed by a second ablation pass accompanied by registering of mass signals. Before ablation, blank signals were always registered within the first $18 \mathrm{~s}$ of argon flow only. Before quantification the blank signal was subtracted for each element individually. ${ }^{43} \mathrm{Ca}$ was used as an internal standard, while the Corning Museum of Glass (CMG) standard B was employed as an external standard; the quantification was validated by using NIST and CMG glass standards.

In Ghent the PerkinElmer Sciex DRCplus and Thermo Corporation X-Series 2 ICP-MS instruments were used. The measurements were carried out using a GeoLas $193 \mathrm{~nm}$ ArF excimer-laser ablation system. A pre-cleaning of the surface was performed with a wider laser-beam than for ablation (120 vs $80 \mu \mathrm{m}$ diameter). A laser output energy of $100 \mathrm{~mJ}$, generating a fluence of $\sim 6 \mathrm{~J} . \mathrm{cm}^{-2}$ on the sample surface, was used throughout all of the measurements. The measurements were performed with a repetition rate of $10 \mathrm{~Hz}$ along a $1.2 \mathrm{~mm}$ long line, with a speed of $0.2 \mathrm{~mm} / \mathrm{s}$ for pre-cleaning and $0.02 \mathrm{~mm} / \mathrm{s}$ for ablation. The most important ICP-MS instrument settings (carrier gas flow rate and RF power) were optimised, aiming at maximum signal intensities, minimal background intensity and low oxide ion and doubly charged ion formation, based upon the signal intensities obtained when ablating NIST SRM 610. The signal intensities, obtained during $60 \mathrm{sec}$ of the signal profile obtained during the line scan, were averaged so that for each nuclide of interest, an intensity value proportional to the concentration of the isotope in the sample was obtained. The average of the blank signal, monitored during twenty seconds at the beginning of each LAICP-MS measurement, was used for blank correction. NIST SRM 610 was analysed in the same way as the Roman black glass samples to act as external standard. During each meas urement, ${ }^{43} \mathrm{Ca}$ was measured as internal standard. The method was validated via the analysis of several NIST standard glasses.

\section{Results}

The obtained glass compositions are reported in Supplementary Table 1 (SEM-EDX data) and Supplementary Table 2 (LA-ICP-MS data). 
The data are expressed in oxide weight percentages (Supplementary Table 1) and $\mu \mathrm{g} / \mathrm{g}$ (Supplementary Table 2).

In the following paragraphs a number of general considerations about the structure of this dataset are provided with the help of oxide bi-plots. For a more detailed description and interpretation of the reported data, we refer the reader to other papers (Van der Linden et al., 2009; Cagno et al. 2014).

All the glass fragments analysed show a silica-soda-lime composition. As shown in Figure 1 , when applying the classification proposed by Henderson (1985), relative to the fluxing agent, the samples mostly fall in the low magnesium glass (LMG) group $\left(\mathrm{K}_{2} \mathrm{O}\right.$ and $\mathrm{MgO}<1.5 \%)$, and partly in the high magnesium glass (HMG) group $\left(\mathrm{K}_{2} \mathrm{O}\right.$ and $\mathrm{MgO}>1.5 \%)$. The LMG-group is totally made of $1^{\text {st }}$ century AD samples.

For what concerns the colouring agents used to obtain a black appearing hue, two main groups are found (Figure 2): i) glass with a dark green hue, colored with iron; ii) glass with a dark purple hue, coloured with manganese.

Next to these, rare samples of glass with a dark blue hue (cobalt and/or copper) and dark brown glass (Fe-S complex) are also present.

The dark green group is by far the largest, represented by many object shapes that were typically only produced in black glass (e.g. bracelets, beads). This group covers all the periods and areas studied.

The black/purple glass samples represent a characteristic production mainly related to pre-Roman bracelets dated $1^{\text {st }}$ century $\mathrm{BC}$ and $1^{\text {st }}$ century $\mathrm{AD}$ and early Roman counters of the $1^{\text {st }}-2^{\text {nd }}$ century AD.

Within the dark green group, which represents about $80 \%$ of the analysed samples, three distinct compositions can be identified: i) Syro-Levantine glass (LMG), plus a variable percentage of $\mathrm{Fe}_{2} \mathrm{O}_{3}$ (4-16\%); ii) high manganese, iron, titanium (HIMT) glass (LMG), plus a variable percentage of $\mathrm{Fe}_{2} \mathrm{O}_{3}$ (4-11\%); iii) HMG glass, with a low percentage of $\mathrm{Fe}_{2} \mathrm{O}_{3}$ (1-3\%).

Iron is responsible for the green hue; because of the high Fe concentration, this results in a very dark color. For the first two groups, the introduction of iron in the glass batch is unlikely to have taken place in the primary Levantine workshops, devoted to the production and trade of widely marketable raw glass, but was probably done in a secondary step, coincident with the reworking and shaping of the raw glass in Western workshops (Van der Linden et al., 2009).

The Syro-Levantine naturally-colored group of glass is the most common in the analysed set (about 50\%) and it is spread throughout almost all the considered sites, from the ones closest to the raw glass workshops (i.e. in Israel, Cyprus) to the farthest ones. The hypothesised raw materials used for its production are lime-rich sand (e.g. from the Belus river, as cited by Pliny) and mineral soda (natron) obtained from inland lakes, (e.g. in Wadi al Natrun, Egypt). When considering the dates attributed to the analysed samples, this composition appears to be typical for the glass from mid $2^{\text {nd }}$ century $\mathrm{AD}$ to the mid $4^{\text {th }}$ century $\mathrm{AD}$, agreeing with the Syro-Levantine (naturally colored) glass time span proposed in the literature (Foster and Jackson, 2009).

The HIMT glass group is comprised of glass from the $4^{\text {th }}$ century onwards and its composition is similar to the reported analyses of HIMT glass in the literature (Foster and Jackson, 2009; Freestone et al., 2005), except for their extremely high iron content. HIMT glass is a late Roman glass composition originating from the Eastern Mediterranean (presumably not from Syro-Palestine) that is richer in $\mathrm{Na}, \mathrm{Mn}$, $\mathrm{Ti}, \mathrm{Fe}$ and is of overall lower quality than the Syro-Levantine glass. The dark green color is generated, as before, by the addition of iron to raw glass in secondary workshops.

The HMG glass is produced by using ash of halophytic plants, (e.g. Salsola Soda) as a fluxing agent. This composition is not typical of Roman glass, but of both earlier and later glass. However, it is reported that during the Roman period in areas not under Roman domination, glass was produced in this manner (Mirti et al., 2008). A few samples of this group are on a line connecting HMG and LMG samples (Figure 1). Thus, it is possible that a mixing process of vegetable and mineral soda was in use at the time, or that recycled glass (cullet) with an LMG composition was added to a batch containing vegetable ash and sand. The HMG samples contain a lower amount of iron oxide than the other groups; iron is also correlated to other Fe-tracers present in the sand, suggesting that no iron was separately added to the batch. Since in most cases the Fe-content in this group is not high enough to give rise to the dark color alone, we must assume that at this stage the thickness and shape of the objects played an important role in the perception of color. Only one HMG sample, originating from Trier, presents a high content of iron $\left(6.9 \% \mathrm{Fe}_{2} \mathrm{O}_{3}\right)$.

The trace element contents can help in identifying specific silica sources: when considering the $\mathrm{Ti}$ and $\mathrm{Zr}$ contents (Figure 3) a distinct difference in sand source is evidenced by the $\mathrm{Zr} / \mathrm{Ti}$ ratio of the HMG-HIMT glass that is different from that of the Syro-Levantine glass. The sand used to produce the HIMT glass appears to be similar to that of the earlier HMG glass, with higher average Ti-content.

Finally, the black/purple glass owes its color to high concentration levels of $\mathrm{MnO}$ ranging from 1.6 to $10.5 \%$. Normally, Mn0 contents of up to $0.6 \%$ are commonly found in Roman (non-purple) glass (Aerts et al., 2003; Brill, 1999; Silvestri et al., 2007) and are attributed to impurities present in the siliceous sand. In the present case, it is clear that a Mn-mineral was intentionally added. Among the Mn-rich samples, a few LMG-HMG intermediate samples are found (Figure 1).

\section{Discussion and Conclusions}

The results presented in this paper on the composition of black-appearing glass from over five centuries offer the possibility of comparing a large amount of data and give a wide overview on the used raw materials and adopted production techniques of Roman glassmak-

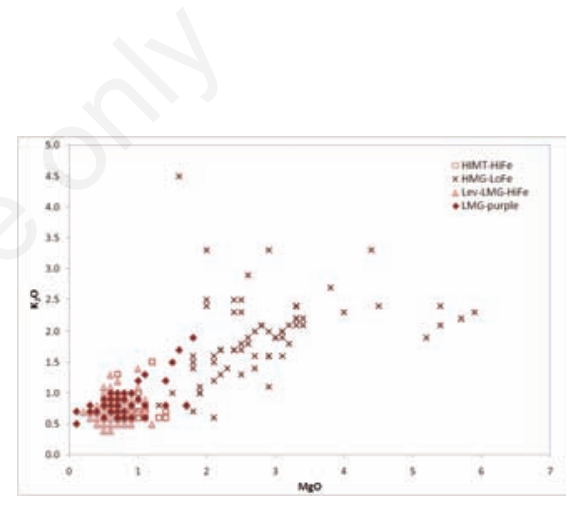

Figure 1. $\mathrm{K}_{2} \mathrm{O}$ and $\mathrm{MgO}$ concentrations in the analysed samples $(\% \mathrm{w} / \mathrm{w})$.

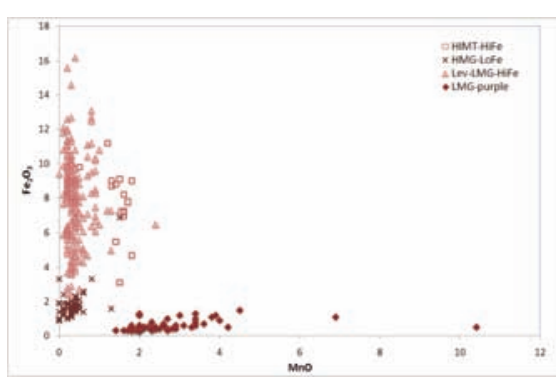

Figure 2. $\mathrm{MnO}$ and $\mathrm{Fe}_{2} \mathrm{O}_{3}$ concentrations in the analysed samples $(\% \mathrm{w} / \mathrm{w})$.

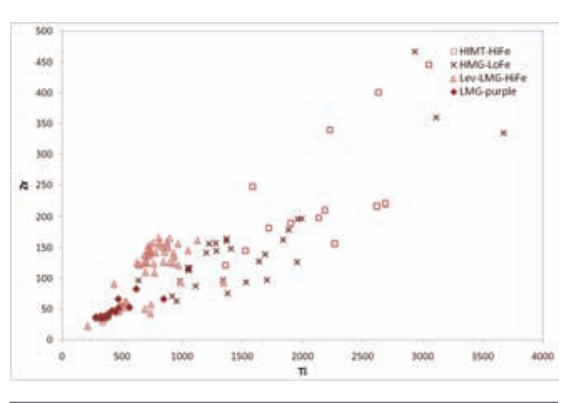

Figure 3. Ti and $\mathrm{Zr}$ concentrations in the analysed samples $(\mu \mathrm{g} / \mathrm{g})$. 
ing. Different raw materials (silica source, flux, coloring agents) have been identified on the basis of the presented data. When combining the compositions with the typological and chronological information, we obtain an account of the black Roman glass compositional history. Two co-existing recipes can be distinguished for the first period of popularity of black glass (until the mid $2^{\text {nd }}$ century AD): one is the black/purple glass, made with SyroLevantine raw glass (produced with relatively pure sand and natron), colored via the addition of manganese, while the other is the dark green glass, with a HMG composition (produced with impure Fe-rich sand and vegetable ash), without deliberate addition of iron. The black purple glass and the HMG glass are rather uniformly distributed but particularly concentrated in the Western provinces.

In the second half of the $2^{\text {nd }}$ century, when black glass became fashionable for a second time, particularly within the North-Western provinces, innovations in glass technology occurred. Although artifacts continued to be made of black/purple glass with the same recipe as before, a big change is noticeable in black/green glass production: the low iron HMG glass disappeared, and got replaced by the Levantine base glass with purely mineral soda and colored with a high amount of iron. This shift in applied glass technology can be related to a higher degree of knowledge acquired in the secondary workshops in the western part of the Roman Empire.

The major change in global glass production that occurred in the Roman Empire during the $4^{\text {th }}$ century is also noticeable in the black glass production. A decline in the use of the more refined Syro-Palestinian raw glass is observed in favor of a less pure, and probably cheaper, HIMT glass. Most $4^{\text {th }}$ century artifacts show the use of HIMT glass and the addition of iron, confirming the hypothesis of the coloring process in secondary workshops, where iron minerals were added to the available raw glass. Considering the variable glass composition and the different hues of the glass that were employed in the five centuries and within the European-Mediterranean area covered by this study, it is possible to conclude that the production of black glass was a process driven by the availability of the starting materials (e.g. the type of raw glass, specific Fe/Mn-minerals) with the aim of obtaining a (macroscopically apparent) black appearance.

\section{References}

Aerts A, Velde B, Janssens K, Dijkman W, 2003. Change in silica sources in Roman and post-Roman glass. Spectrochim Acta B 58:659-67.
Brill RH, 1999. Chemical analyses of early glasses. Corning Museum of Glass, New York.

Cagno S, Cosyns P, Izmer A, Vanhaecke F, Nys K, Janssens K, 2014 (in press). Deeply colored and black-appearing Roman glass: a continued research. J Archaeol Sci 42:12839.

Cosyns P, 2011. The typological, chronological, contextual, technological and archaeometric investigation of the production and use of black glass in the Roman Empire during the 1st to 5th centuries AD. PhD Thesis. Virije Universiteit Brussels ed.

Cosyns P, Fontaine SD, 2009. [Le verre noir romain du ler siècle: un aperçu]. [Proc. in French]. In: [Annales du 17e Congrès de l'Association Internationale pour l'Histoire du Verre (Antwerp, 2006)]. BrusselsAntwerp, pp 80-7.

Cosyns P, Gratuze B, 2007. [La composition chimique des perles en verre de la tombe à char de la nécropole de Neufchâteau-Le Sart par LA-ICP-MS]. [Article in French]. Arduinna 63:1-7.

Cosyns P, Hanut F, 2005. Black glass of second to third-century date in northern Gaul: a preliminary survey. In: Annales of the 16th AIHV Congress, London 2003. AIHV, Nottingham, pp 113-8.

Cosyns P, Hurt P, 2007. [Les perles en verre de Neufchâteau-Le Sart]. [Article in French]. Arduinna 62:1-5.

Cosyns P, Janssens K, Van der Linden V, Schalm 0, 2006. Black glass in the Roman empire: a work in progress. In: G. Creemers, B. Demarsin, P. Cosyns (eds.) Roman glass from Germania Inferior. Interregional comparisons and recent finds, international colloquium, 13th May 2005 Tongeren, Hasselt, Atuatuca 1, pp 30 41.

Degryse P, Schneider J, 2008. Pliny the Elder and Sr-Nd isotopes: tracing the provenance of raw materials for Roman glass production. J Archaeol Sci 35:1993-2000.

Fontaine S, Foy D, 2007. [L'épave OuestEmbiez 1, Var. Le commerce maritime du verre brut et manufacturé en Méditerranée occidentale dans l'Antiquité]. [Article in French]. Revue Archéologique de Narbonnaise 40:235-68.

Foster E, Jackson CM, 2009. The composition of naturally coloured late Roman vessel glass from Britain and the implications for models of glass production and supply. $\mathrm{J}$ Archaeol Sci 36:189-204.

Foy D, 2000. [Téchnologie, géographie, économie: les ateliers de verriers primaires et secondaires en Occident. Esquisse d'une évolution de l'Antiquité au Moyen Âge]. [Book in French]. Maison de l'Orient Méditerranéen, Lyon. pp 147-70.

Foy D, Vichy M, Picon M, 2000. [Lingots de verre en Méditerranée (IIIe s. av. J.-C.-VIIe s. ap. J.-C.), approvisionnement et mise en oeuvre; les données archéologiques et les données de laboratoire]. [Proc. in French]. In: Annales of the 15th AIHV Congress, Venise-Milan 1998. Lochem, AIHV, pp 51-7.

Freestone IC, 2006. Glass production in late antiquity and the early Islamic period: a geochemical perspective. In: M. Maggetti, B. Messiga (eds.) Geomaterials in cultural heritage. Geological Society of London Special Publication, London, pp 201-16.

Freestone IC, Gorin-Rosen Y, Hughes MJ, 2000. Composition of primary glass from Israel. Maison de l'Orient Méditerranéen, Lyon, pp 65-84.

Freestone IC, Wolf S, Thirlwall M, 2005. The production of HIMT glass: elemental and isotopic evidence. In: Annales of the 16th AIHV Congress, London 2003. AIHV, Nottingham, pp 153-7.

Gratuze B, 2009. [Les premiers verres au natron retrouvés en Europe Occidentale: composition chimique et chrono-typologie]. [Proc. in French]. In: Annales of the $17^{\text {th }}$ AIHV Congress, Antwerp 2006. AIHV, Brussels, pp 8-14.

Henderson J, 1985. The raw materials of early glass production. Oxford J Archaeol 4:26791.

Jackson CM, Price J, Lemke C, 2009. Glass production in the 1st century AD. In: Annales of the $17^{\text {th }}$ AIHV Congress, Antwerp 2006. Brussels, AIHV, pp 150-6.

Mirti P, Pace M, Negro Ponzi MM, Aceto M, 2008. ICP-MS analysis of glass fragments of Parthian and Sasanian epoch from Seleucia and Veh Ardaš r (Central Iraq). Archaeometry 50:429-50.

Nenna MD, 2008. [Production et commerce du verre à l'époque impériale: nouvelle découvertes et problématiques]. [Article in French]. Facta 1:125-47.

Picon M, Vichy MD, 2003. ['Orient en occident: l'origine du verre à l'époque romaine et durant le haut moyenâge]. In: D. Foy, M.D. Nenna (eds.) [Échanges et commerce du verre dans le monde antique]. [Book in French]. Monique Mergoil, Montignac, pp 17-31.

Reade W, Freestone IC, Bourke S. Innovation and continuity in Bronze an Iron Age glass from Pella in Jordan. In: Annales of the $17^{\text {th }}$ AIHV Congress, Antwerp 2006. AIHV, Brussels, 2009, pp 47-54.

Schalm 0, Janssens K, 2003. A flexible and accurate quantification algorithm for electron probe x-ray microanalysis based on thin-film element yields. Spectrochim Acta B 58:669-80.

Shortland A, Schachner L, Freestone IC, Tite M, 2006. Natron as a flux in the early vitreous materials industry: sources, begin- 
nings and reason for decline. J Archaeol Sci 33:521-30.

Silvestri A, Molin G, Salviulo G, 2007. The colourless glass of Iulia Felix. J Archaeol Sci 35:331-41.

Silvestri A, Molin G, Salviulo G, Schievenin R, 2006. Sand for Roman glass production: an experimental and philological study on source and supply. Archaeometry 48:41532.

Stern EM, 1999. Roman glassblowing in a cul- tural context. Am J Archaeol 103:441-84.

Stern EM, Schlick-Nolte B, 1994. Early glass of the ancient world $1600 \mathrm{BC}$ to $\mathrm{AD} 50$, Ernesto Wolf Collection. Verlag Gerd Hatje, Ostfildern.

Van der Linden V, Cosyns P, Schalm 0, Cagno S, Nys K, Janssens K, 2009. Deeply coloured and black glass in the northern provinces of the Roman Empire: differences and similarities in chemical composition before and after 150 AD.
Archaeometry 51:822-44.

Velde B, 1990. Alumina and calcium oxide contents of glasses found in western and northern Europe, first to ninth century. Oxford J Archaeol 9:105-17.

Wedepohl H, Baumann A, 2000. The use of marine molluskan shells for Roman glass and local raw glass production in the Eifel area (western Germany). Naturwissen schaften 87:129-32. 